\title{
P323: Epidemiological study of drug administration routes (dar) in the department of pediatrics, Gabriel Touré hospital. Mali
}

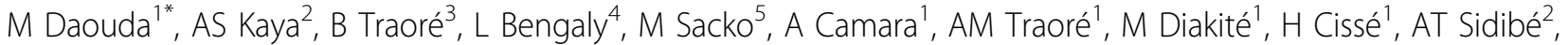 \\ HA Traoré ${ }^{2}$ 'T Sidibé ${ }^{3}$, MM Keita $^{3}$
}

From 2nd International Conference on Prevention and Infection Control (ICPIC 2013)

Geneva, Switzerland. 25-28 June 2013

\section{Objectives}

Injectable route seems to be the most frequently used in health facilities in a resource-limited setting.

\section{Methods}

In order to better understand this under investigated issue, we conducted a longitudinal study of DAR use in the general pediatric ward of the Gabriel Touré Hospital to Bamako during 6 months.

\section{Results}

We are interested in the routes of administration applied to a population of 300 children with a sex ratio $(\mathrm{M} / \mathrm{F})=$ 1.3. Their average age was 2 years \pm 1 . Presumed diagnoses underwent a change from admission to discharge, both in frequency and formulation. Malaria (37.4\% vs $39.7 \%$ at 72 hours), pneumonia (19\% vs $20 \%$ at 72 hours), and the nephrotic syndrome ( $2.2 \%$ vs. $5.1 \%$ in 72 hours) were most commonly mentioned. Treatments prescribed for the presumed diagnosis were administered parenterally in $76.6 \%$ of cases at admission, in $70 \% 72 \mathrm{~h}$ hours after admission and in $36.3 \%$ at discharge. The following complications were noted: inflammation of the catheter puncture sites $(21.8 \%$ at admission, $18 \%$ after 5 days of hospitalization), abscess at the site of intramuscular injection $(2.1 \%)$. The mean duration of hospitalization was $7.6 \pm 3.7$ days and mortality was $11 \%$.

\section{Conclusion}

Injection is the most widely used in the pediatric unit III for the most common pathologies. A detailed study

Service of Infectious Diseases,Department of Public Health, Faculty of Medicine, Bamako, Mali

Full list of author information is available at the end of the article would be needed to assess the adequacy of the diagnostic hypotheses and routes of administration. The high number of injections exposes staff and patients to risks.

\section{Disclosure of interest}

None declared.

\section{Author details}

'Service of Infectious Diseases,Department of Public Health, Faculty of Medicine, Bamako, Mali. ${ }^{2}$ Department of Internal medecine, University Hospital of Point G, Department of Public Health, Faculty of Medicine, Bamako, Mali. ${ }^{3}$ Pediatric Services, Department of Public Health, Faculty of Medicine, Bamako, Mali. ${ }^{4}$ Hospital Pharmacy, CHU Gabriel Touré, Department of Public Health, Faculty of Medicine, Bamako, Mali. ${ }^{5}$ Department of Public Health, Faculty of Medicine, Bamako, Mali.

Published: 20 June 2013

\section{doi:10.1186/2047-2994-2-S1-P323}

Cite this article as: Daouda et al.: P323: Epidemiological study of drug administration routes (dar) in the department of pediatrics, Gabriel Touré hospital. Mali. Antimicrobial Resistance and Infection Control 2013 2(Suppl 1): P323.

Submit your next manuscript to BioMed Central and take full advantage of:

- Convenient online submission

- Thorough peer review

- No space constraints or color figure charges

- Immediate publication on acceptance

- Inclusion in PubMed, CAS, Scopus and Google Scholar

- Research which is freely available for redistribution

\section{Biomed Central}

